\title{
有機系吸着分子の電子・イオン誘起反応
}

\author{
正 員 持地 広造*
}

\section{Electron and Ion-Induced Reactions of Organic Molecules Adsorbed on the Surfaces}

Kozo Mochiji*, Member

The studies on the chemical reactions of organic molecules induced by low-energy electrons and gas cluster ions are reviewed. The author's group has developed the in-situ observation technique for electron-irradiated surfaces. The technique employs a scanning tunneling microscope as a field-emitted electron source, as well as a probe for surface analysis. By using the technique, we have investigated the effect of low-energy-electron irradiations to adsorbed molecules, such as ethylene and DNA. Desorption, dissociation of the molecules and changes to other chemical species, were observed, depending on electron energy and electron dosage. When a gas cluster ion, consisting of thousands of atoms or molecules, collides with a solid surface, several types of reactions are uniquely induced at the surface. The average kinetic energy of a constituent atom of the cluster can be defined by dividing the acceleration energy by the number of constituent atoms. Thus, very low-energy-ion irradiation is easily achieved by using large cluster ions. DNA adsorbed graphite surfaces were irradiated with argon(Ar) gas cluster ions. The secondary ion yield and the structural changes of the surfaces were investigated. These results are compared with the case by the irradiation with monomer ions $\left(\mathrm{Ar}^{+}\right)$and are discussed from the view point of the kinetic energy of a constituent atom of the cluster ion.

キーワード : 電子, ガスクラスターイオン, 有機分子, エチレン, グラファイト, DNA, 走査トンネル顕微鏡

Keywords : electron, gas cluster ion, organic molecule, ethylene, graphite, DNA, STM

\section{1. はじめに}

電子, イオン，光などのビーム利用技術は半導体微細加 工への応用をきっかけとして著しい進歩を遂げてきた。そ の加工サイズはマイクロメートルからナノメートル，そし て原子オーダーへと近づきつつある。一方でこれらのビー ム利用技術は半導体分野以外にバイオ工学や医療などにも 活発に利用されるようになってきている。これらの分野で はさまざまな有機分子や高分子，あるいはこれらの有機系 物質と無機・金属などとの複合材料が対象となる。無機物 質や金属材料のビーム誘起反応に関する報告はこれまで多 くなされているが，有機系物質に関しての研究報告は少な い(1)〜(3)。とくに，低エネルギーの電子やイオンの照射効果 については極めて少ない。著者らは，2，3 の有機分子をモ デルとして低エネルギーの電子あるいはイオンの照射効果 を検討してきたので報告する。

\section{2. 低エネルギー電子照射効果}

\section{〈2·1〉電子照射「その場」観察方法＼cjkstart現在，微細な}

\footnotetext{
兵庫県立大学大学院 工学研究科

干671-2280 兵庫県姫路市書写 2167

Graduate School of Engineering, University of Hyogo

2167 Shosha, Himeji, Hyogo 671-2280
}

電子線や STM (Scanning Tunneling Microscope, 走査トンネ ル顕微鏡）を利用して表面を原子・分子レベルで操作する 研究が活発化している。一般に電子線やSTMによって生じ る反応では, 数 $10 \mathrm{eV}$ 以下の低エネルギー電子 (トンネル電 流を含む）と吸着分子との相互作用が重要な鍵を握ってい る。しかし，これまでいくつかの原子や分子の操作例が報 告されているが(4), 低エネルギー電子線照射による吸着分子 の反応機構を基礎的な立場から検討した例は少ない。 我々はこれまで，STM 探針からの電界放射電子を照射ビ 一ム源として利用する方法を独自に開発してきた (図 1) ${ }^{(5)}$ 。 この方法の特長は, (1) 数 $10 \mathrm{eV}$ 以下の電子が一般の電子銃 より 4〜5 桁高い照射密度で得られる, (2) 電子源である STM 探針をそのままプローブに使う事により, 電子ビーム 照射前後の構造変化を原子レベルで比較できる, (3) 電子ビ ームサイズを $10 \mathrm{~nm}$ 以下にできるので, 吸着量を抑える事に よって単一分子への照射効果を調べる事が可能，等である。 また,この手法は, 試料を探針に近づけて $(<1 \mathrm{~nm})$ トンネ ル電流で行う原子マニピュレーションと比べると, 探針の 先鋭度に左右されにくい為, 再現性及び安定性が高いとい う利点がある。

この観察方法を $\mathrm{Si}(100)$ 表面に吸着させたエチレン分子や HOPG (Highly Oriented Pyrolytic Graphite, 高配向性熱分解グ 


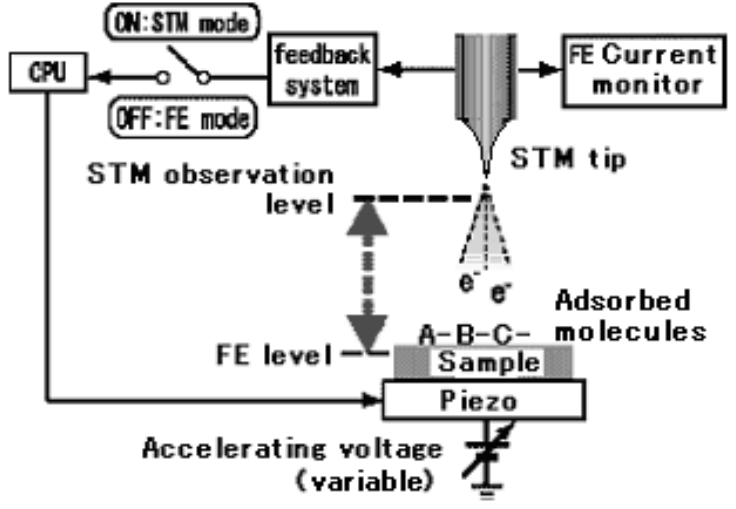

図 1 電子線照射その場観察方法

Fig. 1. The in-situ observation system for electron-irradiated surfaces.

ラファイト）表面に吸着させた DNA 分子に適用し，電子線 照射による吸着分子の構造変化を検討してきた ${ }^{(6)}$ 。

〈2·2〉 吸着エチレンへの電子照射効果 エチレン分 子 $\left(\mathrm{C}_{2} \mathrm{H}_{4}\right)$ は不飽和炭化水素の中で最も基本的な分子であり, $\operatorname{Si}(100)$ 表面への吸着状態について 2，3 の報告がある。この 吸着状態に含まれる結合の種類は, $\mathrm{C}-\mathrm{Si}, \mathrm{C}-\mathrm{H}, \mathrm{C}-\mathrm{C}$, $\mathrm{Si}-\mathrm{Si}$ の四種類のみである。電子照射によって, どの結合が 切断されるか，あるいはどの様な結合の組み替えが起こる のかを解明できれば，より複雑な分子(例えば DNA 等の生 体高分子)の反応を解明する手掛かりとなる。

本研究では $1200^{\circ} \mathrm{C}$ 付近の加熱処理によって酸化膜などを 除去して形成した Si(100)-2x1 表面にエチレンガスを曝露さ せて吸着表面を作成した。エチレン分子は自身の二重結合 を開裂し，同じく開裂された Si(100)-2x1 表面の Si ダイマー の $\pi$ 結合と 2 本の $\sigma$ 結合を新たに形成するものと解釈され ている(図 2) $)^{(7)}$ 。

エチレン吸着表面の STM 像を図 3(a)に示す。エチレン吸 着位置は清浄なダイマーと比べて少し暗く, やや細い形状 をしている(矢印部)。この表面に電子（エネルギー： $50 \mathrm{eV}$, 照射量：50nA·s）を照射した後の STM 像を図 3(b)に示す。

照射後の表面では，大半の吸着エチレンは消滅している が，照射前には存在しない，大きさが 1 ダイマー程度でほ ぼ円形の明るい点(小明点)と, 大きさが 2 ダイマー程度でほ ぼ円形の明るい点(大明点)が現れている。消滅した吸着エチ レンは，電子線照射によって脱離したものと考えられる。 これらの結果より, 電子線照射による吸着エチレンの反応 には，脱離反応と明点への変化の大きく 2 通りの経路があ ることが判明した。ここで，小明点は電子線照射量が低い ときのみ観察され，2mA・s 程度まで増やした表面では存在 が認められなかった。したがって，電子線照射によりエチ レン吸着部はまず小明点に変化するが，これは不安定であ り別の構造をもつ大明点に変化し易いものと解釈される。 いったん生成された大明点の多くは，その後の電子照射に よって形状が変化しにくいという特徵が認められた。この ことは, 電子照射によって, エチレン吸着状態が最終的に

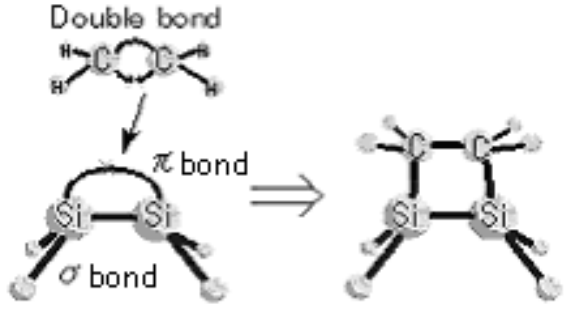

図 2 エチレンの $\operatorname{Si}(100)$ への吸着モデル

Fig. 2. The model of adsorption of ethylene to $\mathrm{Si}(100)$.

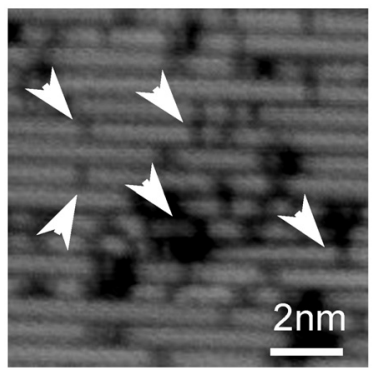

(a)

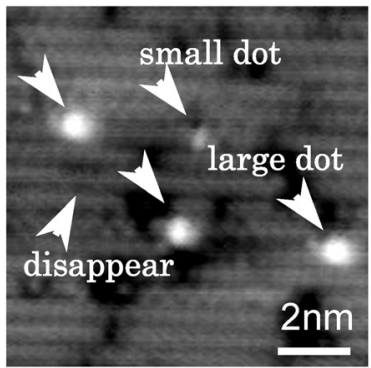

(b)
図 3 エチレン吸着 $\operatorname{Si}(100)$ 一の電子線照射

Fig. 3. Electron-irradiation to ethylene-chemisorbed Si (100) surface.

は電子照射に対して安定な状態に変化していることを示す ものである。

以上の結果を次の様に考察した。電子照射により，エチ レン分子内の $4 つ の \mathrm{C}-\mathrm{H}$ 結合が切断されれば水素原子が脱 離し，4 本の破断結合が残りうる。破断結合は STM で明る く観察される可能性が高いので, 上記の小明点は, この水 素が脱離した状態のエチレン(以下, 脱水素エチレン)である 可能性が高い。我々の研究グループにおいて, 電子照射時 の脱離イオンを飛行時間法(TOF)により計測した結果, 水素 イオン $\left(\mathrm{H}^{+}\right)$が検出されている。この結果は, 上記の解釈を裏 付けるものである。

破断結合を含んだ脱水素エチレンは反応性が高く，隣接 するダイマーにエチレンが吸着している場合には，互いに 反応（重合）してシクロブタン $\left(\mathrm{C}_{4} \mathrm{H}_{4}\right)$ を形成する事が可能 である(図 4)。ここで, 電子照射によっていったん脱離した エチレンが, 脱水素エチレンの近傍に再吸着する事も十分 考えられる。このシクロブタンは，4 本の $\mathrm{C}-\mathrm{Si}$ 結合で $\mathrm{Si}$ に吸着しているため電子照射に対して安定であると考えら れる。気相中のエチレンは, 放射線照射によって重合反応 を起こす事はよく知られている。本研究で取り上げた反応 は，吸着状態における重合反応とみなすことができる。

〈2.3〉 吸着 DNA 分子への電子照射効果 現在, 癌治 療の分野において高エネルギーの放射線や粒子線の照射を 利用した方法が行われている ${ }^{(8)(9)}$ 。放射線や粒子線の照射効 果には, DNA を電離して直接分子を切断する過程（直接効 果）及び, 周辺の原子（水など）を電離し，これらが化学 的に DNA を切断する過程（間接効果）がある。いずれの過 


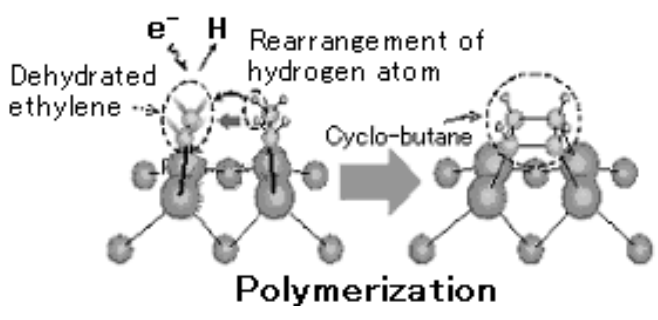

図 4 脱水素エチレンとエチレンの反応過程

Fig. 4. Reaction process between dehydrogenated ethylene and ethylene.

程でも電離作用によって大量の二次電子が発生する。これ らの大半は $20 \mathrm{eV}$ 以下の低エネルギーであり,これまで DNA 切断には影響を与えないと考えられてきた。しかし 2000 年 頃より，このような低エネルギーの二次電子も重要な影響 を与えうるという報告がなされるようになってきた ${ }^{(10)(11)}$ 。 これらの事例として，20 eV 以下のエネルギーの電子照射に より DNA 分子の切断が起こることや, $5 \mathrm{eV}$ 以下の電子照射 によってDNAの塩基が破壊されることなどが報告されてい $る^{(12)(13)}$ 。しかし現状では低エネルギー電子照射効果に関す る報告は数もまだ少なく，照射効果の機構には多くの不明 な点が残されている。

本研究では, 低エネルギー電子照射効果の機構解明の第 一歩として，低エネルギー電子を照射した場合の DNA 分子 の形状変化を直接観察することを目的とした。これまでに 電子照射によるDNA 分子の形状変化を観察した例は報告さ れていない。著者らは, グラファイトに付着させた DNA 分 子に STM 探針からの電界放射電子を照射し，照射前後の分 子形状の変化を STM で解析し検討してきた。

DNA 試料として環状型のプラスミドDNA（2686塩基対) を使用した。緩衝㶡等を含んだ DNA 水溶液をグラファイト 基板上に滴下して, 流水と窒素ガスによって溶媒を洗い流 して乾燥させた。グラファイトに付着させた DNA 試料の STM 像の一例を図 5 に示寸。環状 DNA はネットワーク状 に観察され，ネットワークを構成する DNA 部分の幅は明ら かに DNA1 分子の幅（約 $2 \mathrm{~nm}$ ）より大きい。これは複数の 環状 DNA 分子が部分的に凝集しているか，あるいは同一の 分子内で分子鎖が据れて接触しているためと考えられる。

付着状態にあるDNAに何種類かのエネルギーの電子を照 射し，照射前後のSTM 像を比較した結果を図 6 および図 7 に示す。 $8 \mathrm{eV}$ あるいは $13 \mathrm{eV}$ のエネルギーの電子照射では, DNA 領域の増加が観察された（図 6(a) $\rightarrow(\mathrm{b}))$ 。しかし，この 増加現象はある程度の電子照射量で飽和寸る傾向にあった

(図 6(b) $\rightarrow(\mathrm{c}))$ 。一方，18eV では逆に DNA 領域の周辺が消

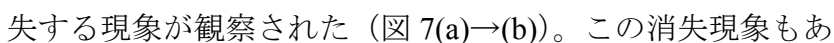
る程度の電子照射量で飽和する傾向が見られた（図 7(b) $\rightarrow$ (c))。さらに $38 \mathrm{eV}$ では, 増加と消失との両方が起こってい た。以上の結果は, 照射電子のエネルギーによって DNA 分 子が異なるタイプの化学反応を起こしていることを示唆す るものである。

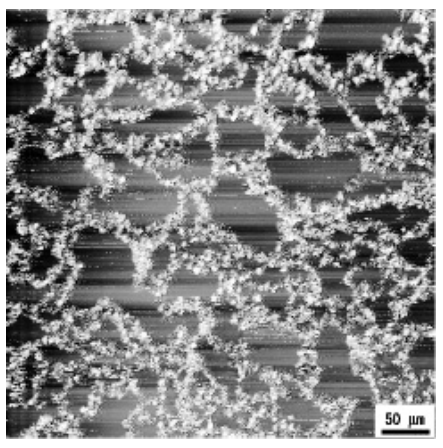

図 5 グラファイトに付着したプラスミド DNA の STM 像

Fig. 5. STM image of plasmid DNA on graphite.
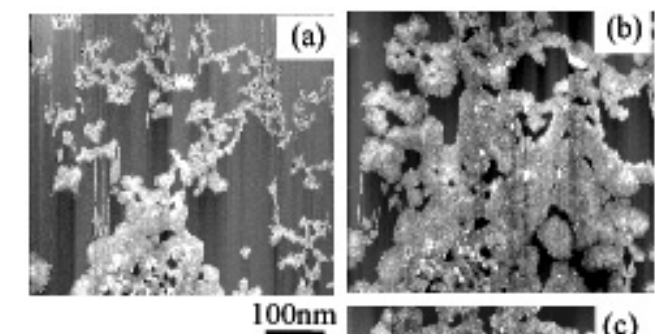

(a) before irradiation

(b) after irradiation dose: $0.15 \mathrm{nAsnm}^{-2}$

(c) after irradiation dose: $0.3 \mathrm{nAsnm}^{-2}$

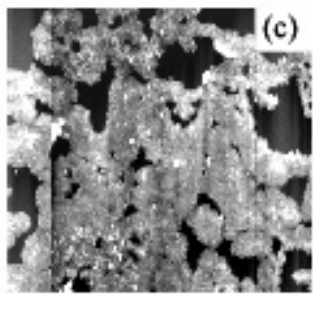

図 $68 \mathrm{eV}$ 電子の照射前後における DNA の STM 像

Fig. 6. STM images of DNA before and after irradiation With $8 \mathrm{eV}$ electrons.

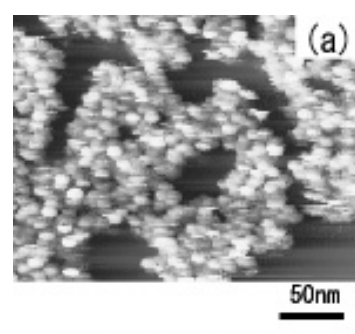

(a) before irradiation

(b) after irradiation dose:0. $15 \mathrm{nAsnm}$

(c) after irradiation dose: 0.3 nAsnm

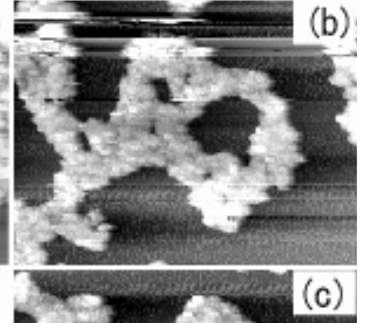

(b)

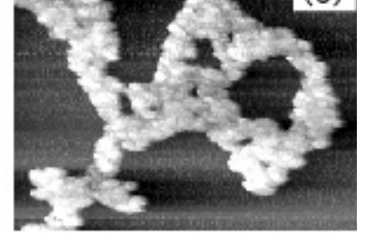

図 $7 \quad 18 \mathrm{eV}$ 電子の照射前後における DNA の STM 像

Fig. 7. STM images of DNA before and after irradiation with $18 \mathrm{eV}$ electrons.

Sanche らは, 薄膜状態のプラスミド DNA 分子の電子照射 による主鎖切断の収率に対する電子エネルギー依存性を電 気泳動法によって調べている(14)。彼らの報告によれば, DNA 分子の主鎖切断には, 一重鎖切断, 二重鎖切断, 多重鎖切 断の 3 種類のタイプが存在する。ここで, 一重鎖切断, 二 
重鎖切断とはDNA 分子の一重鎖あるいは二重鎖が一箇所の み切断された状態であり, 多重鎖切断とは分子の二重鎖が 2 箇所以上切断されている状態, すなわち初期の環状分子 の周長より短い線状形態になったものである。それぞれの 切断反応は照射電子のエネルギーによって共鳴的 (resonantly), あるいは非共鳴的(nonresonantly)に起きると解 析されている。共鳴反応とは, 照射電子 1 個のエネルギー が全て吸収されて起きる反応であり, 非共鳴反応とは, 電 子エネルギーの一部が吸収されて起きる反応である。それ ぞれの切断反応を起こし得る電子エネルギーの領域に関す る Sanche らの解析結果を表 1 にまとめる。DNA 分子の切断 反応は $10^{4}$ 個の電子照射あたり 1 回程度のオーダーで起きる と報告されている。 $15 \mathrm{eV}$ 以下の領域で共鳴的に起きる一重 鎖および二重鎖の切断については次のように解釈されてい る。これらの低エネルギー電子は DNA 分子に付着し, いっ たん負の分子イオン状態を形成する。しかし, これらは不 安定で寿命が短いため, より安定な負イオンと中性の化学 種に解離する（解離性電子付着反応）。この解離反応によっ て DNA の主鎖が切断されるというものである。彼らは電子 照射時に脱離する負イオンを計測し，負イオン収率と主鎖 切断収率の電子エネルギー依存性がよく対応していること から上記の解釈の妥当性を主張している。

今回我々が観察した DNA の形状変化を Sanche らの結果 と比較することによりつぎのように考察することができ る。

DNA 分子の一重鎖あるいは二重鎖の 1 箇所が切断される と, ストレスの大きい二重鎖構造が部分的にほどかれて緩 和された状態になる。 $8 \mathrm{eV}$ あるいは $13 \mathrm{eV}$ の電子照射によっ てDNAの付着領域が増加して観察されたのはこの緩和効果 によって DNA 分子が拡張された状態が STM 分解能の制約 で観察されたものと推定される。一方, 電子エネルギー $18 \mathrm{eV}$ の条件では多重鎖切断が共鳴的に起こり始めるのでDNAが 分解し, これらのフラグメントが脱離することにより付着 領域の消失が生じるものと解釈される。さらに $38 \mathrm{eV}$ の照射 条件ではすべてのタイプの切断反応が生じることによって 付着領域の増加と消失が観察されたものと考えられる。

すでに述べたようにこのDNAの増加および消失現象はあ る程度の電子照射量で飽和する傾向にある。ここで, 電子 照射によってDNAが付着している領域の一部が消失する場 合, その高さは増加することが判った。これは, DNA 分子 が分解反応とともに新たな反応を起こすことによって原子

表 1 DNA の各種主鎖切断を起こす電子エネルギー Table 1. Electron energies for DNA strand breaks ${ }^{(14)}$.

\begin{tabular}{|c|c|c|}
\hline 反応機椠 & 共鳴 & 非共鳴 \\
\hline 一重鎖切断 & $3-15 \mathrm{eV}$ & $>15 \mathrm{eV}$ \\
\hline 二重鎖切断 & $6-15 \mathrm{eV}$ & $>15 \mathrm{eV}$ \\
\hline 多重鎖切断 & $20-30 \mathrm{eV}$ & $>30 \mathrm{eV}$ \\
\hline
\end{tabular}

構造の組み換えが生じ, 高さ方向に増加したものと考えら れる。一般に, 放射線照射によって分解しやすい高分子物 質でも, 非常に多量の照射量を与えると架橋反応を起こす ようになり, 分解反応が抑えられる。DNA 分子においても, 高エネルギーの電子照射によって架橋がおこることが報告 されている ${ }^{(15)}$ 。上にのべた DNA 変化の飽和傾向も架橋反応 によるものと考えられる。

\section{3. ガスクラスターイオン照射効果}

〈3・1〉 ガスクラスターイオン照射効果の特長 ガス クラスターイオンとは, 多数の気体原子がファンデルワール スカなどの分子間力によって集合したクラスターのイオン である。ガスクラスターイオンの照射効果の特長として, (1) イオンを構成する一原子あたりの平均の運動エネルギーは, 加速エネルギーを構成原子数で割った值になる。例えば, 1000 個のアルゴン(Ar)原子で構成されるクラスターイオン を $1 \mathrm{kV}$ で加速した場合, $\mathrm{Ar}$ 原子 1 個あたりの運動エネルギ 一はたかだか $1 \mathrm{eV}$ である。(2)極浅い表面層のみにクラスタ 一の原子密度に相当する高密度のエネルギーが付与される ため入射イオン 1 個あたりのスパッタ収率が高い (図 8) ${ }^{(16)}$ 。

〈3·2〉 ガスクラスターイオン照射装置図 9 にガス クラスターイオン照射装置の構成を示す。クラスター生成 部において, 数気圧程度の試料ガスを $0.1 \mathrm{~mm}$ 程度の微小口 径ノズルを通して真空中に噴射させたとき, ガスの断熱膨 張による冷却効果によってクラスターが生成する。この時 のクラスターサイズは, 原理的には, ガス圧力, ノズル径, ガスの温度, 沸点, 比熱によって決まる。現状ではサイズ 10000 以上のクラスターを生成することができる。これまで に $\mathrm{Ar}$ などの不活性原子に加えて酸素 $\left(\mathrm{O}_{2}\right)$ や六フッ化硫黄

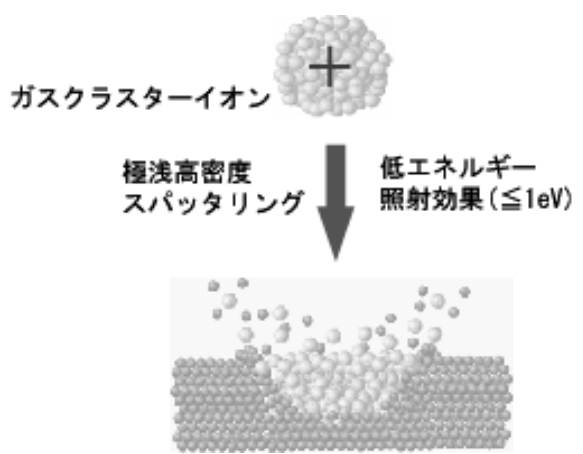

図 8 ガスクラスターイオン照射効果

Fig. 8. Effects of gas cluster ion irradiation.

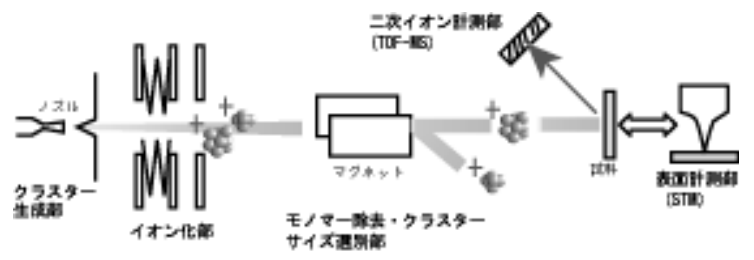

図 9 ガスクラスターイオン照射装置の構成

Fig. 9. Schematic of gas cluster ion irradiation apparatus. 
$\left(\mathrm{SF}_{6}\right)$ などの分子のガスクラスターを生成している。上記の 方法により生成されたクラスターを電子衝撃によってイオ ン化する。このイオン化段階ではクラスターイオンのサイ ズ（構成原子数）は分布を持っており, 分布形状はクラス ターの生成条件によって決まる。なかには，原料の原子あ るいは分子のままのイオン（モノマーイオン）も存在する。 イオン化部の後方に設置したマグネットの磁場の偏向作用 により，モノマーイオンを除去したり，クラスターサイズ を選別できるようにしている。

〈3·3〉 グラファイトおよび DNA への照射効果 $\mathrm{Ar}$ クラスターイオンを照射したグラファイト表面を走查トン ネル顕微鏡(STM)で観察すると, 図 10 に示すようなクレー ター状の大きな照射痕が発生する。従来用いられていたモ ノマーイオンの照射ではこのようなクレーター状の照射痕 は発生せず，照射痕のサイズも 1 桁以上小さい。これは, クラスターイオンを構成する多数の原子が同時に同じ場所 に入射することになるのでこれらの衝突現象が干渉し合う ことによって，モノマーイオンの衝突とは異なる照射効果 を生じるためである。クラスターイオンの構成原子数（ク ラスターサイズ）を変えてこの照射痕の発生状況を調べた 結果, 照射痕発生にクラスターサイズのしきい值があるこ とが判明した。上記のクラスターサイズのしきい值と加速 エネルギー值から, 照射痕の発生に必要な運動エネルギー はクラスターの構成原子 1 個あたり約 $10 \mathrm{eV}$ であることが判 った ${ }^{(17)}$ 。グラファイトにおいて, 1 つの炭素原子は周囲の 3 個の炭素原子と結合している（層間結合は無視）こと，お よび炭素間の結合エネルギーが 1 本あたり $3.5 \mathrm{eV}$ 程度である ことを考慮すると，上記の運動エネルギーのしきい值は 3 本の炭素原子間の結合を同時に切断されるために必要な值 に近いことがわかる。この実験結果は重要な可能性を示唆 する。すなわち, クラスターイオンの構成原子数を調整し て1原子あたりの運動エネルギーを制御することによって, 試料表面の化学結合を選択的に切断できるという可能性で ある。

次に著者らは, DNA 分子を物理吸着させたグラファイト 表面にガスクラスターイオンを照射して二次イオンの発生 と表面の構造変化を調べた。図 11(a)は Ar ガスクラスターイ

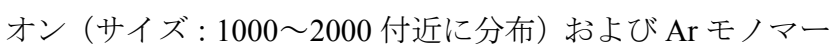
イオンの照射によって試料表面から放出される二次イオン の飛行時間スペクトルを示す。イオンの加速電圧および照 射量はどちらも $5 \mathrm{kV}$ および $3 \times 10^{11} / \mathrm{cm}^{2}$ である。ガスクラス ターイオン照射の方がモノマーイオン照射の場合に比べて 二次イオン強度が 1 桁以上大きく，その飛行時間も 1 桁以 上長い。質量に換算すれば 2 桁以上重い成分が多く含まれ ていることがわかる。これは, ガスクラスターイオンの構 成原子あたりの運動エネルギーが極めて低い $(2.5 \sim 5 \mathrm{eV}) こ$ とによってDNA分子内の解離が抑えられているためと考え られる。図 11(b)(c) は，それぞれイオン照射した後の試料 表面の STM 像である。ガスクラスターイオン照射の場合, DNA がスパッタ除去された表面にはイオン照射痕は観察さ

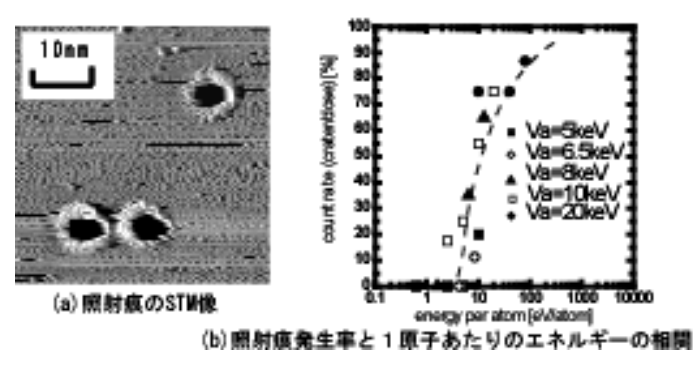

図10 グラファイトの照射痕に及ぼす イオンエネルギーの影響

Fig. 10. The effect of ion energy on irradiation traces on graphite.
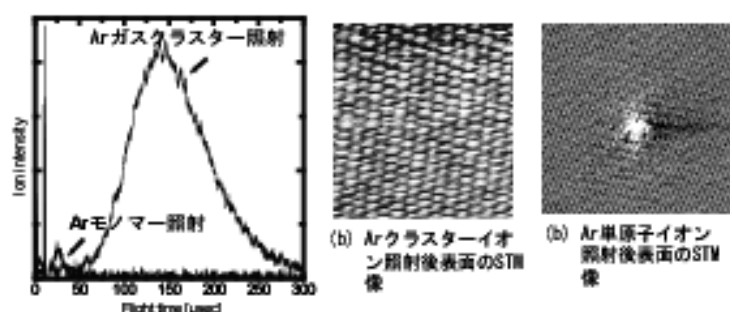

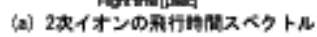

図 11 DNA を吸着させたグラファイトへの イオン照射効果

Fig. 11. Ion irradiation effects on DNA-adsorbed graphite.

れておらず無損傷なグラファイトの原子構造が確認され る。これは, 照射したクラスターイオンの構成原子 1 個あ たりの運動エネルギーが DNA を脱離させるのには十分であ るが，グラファイトに照射痕を発生させるには至らないた めと解䣋できる。一方, モノマーイオン照射の場合は, 明 点状の欠陥が発生している。以上の結果から, ガスクラス ターイオンの一原子あたりの運動エネルギーを調整して照 射することによって, 分子の化学結合を選択的に切断した り, あるいは下地基盤の表面に損傷を与えることなく表面 の吸着分子のみを脱離させることなどが可能になるものと 期待される。

\section{4. おわりに}

STM を利用した低エネルギー電子照射による分子構造変 化のその場観察, およびガスクラスターイオンを利用した 極低エネルギーイオン照射効果について述べてきた。はじ めにも述べたように, 低エネルギー電子の DNA への影響は 環境放射線やビーム医療などの観点からも極めて重要なテ 一マである。現状では試料の DNA が部分的に凝集状態にあ るため単一分子の挙動を明らかにできていない。今後, 試 料調製の方法を検討することにより単一分子状態での照射 効果を究明していく必要がある。ガスクラスターイオン利 用では, クラスター構成原子あたりの運動エネルギーを制 御することにより損傷の極めて少ない加工技術や計測技術 が可能になるものと期待される。例えば, 二次イオン質量 
分析(SIMS)では有機分子などの試料を非破壊で分析するた めにクラスターイオンが一次イオンとして利用されつつあ る。しかしこれまでに使用されているクラスターは $\mathrm{C}_{60}$ や金 属クラスターなど小さなサイズのものに限られている。今 後, 巨大サイズのガスクラスターイオンを一次イオンに利 用することができれば，たんぱく質など生体高分子の SIMS 計測も可能になるかもしれない。

(平成 18 年 11 月 28 日受付)

\section{文献}

(1) E. S. Parilis, et al. : "Atomic collision on solid surfaces", North-Holland, (1993)

(2) F. Aumayer and H. Winter, eds : "Photonic, electronic and atomic collisions", World Scientific (1997)

(3) C. D. Lin, ed : "Review of fundamental processes and applications of atoms and ions", World Scientific (1993)

(4) C. Bai : "Scanning tunneling microscopy and its applications", Springer Ser. Surf. Sci., Vol.32, Springer (2000)

(5) K. Mochiji and M. Ichikawa : "Atomic structural changes of a Br-chemisorbed Si (111)-7x7 surface under 10-150 eV electron impact", Phys. Rev. B Vol.62, pp.2029-2033 (2000)

(6) T. Hasegawa, K. Mochiji, H. Imai, and T. Mitamura : "Electron-induced modification of ethylene molecules chemisorbed on $\mathrm{Si}(100)$ surface", Jpn. J. Appl. Phys. Vol.44, pp.3222-3225 (2005)

(7) J. Yoshinobu, H. Tsuda, M. Onchi, and M. Nishijima : "The adsorbed states of ethylene on $\mathrm{Si}(100) \mathrm{c}(4 \times 2), \mathrm{Si}(100)(2 \times 1)$, and vicinal $\mathrm{Si}(100) 9^{\circ}$ ", J. Chem. Phys. Vol.87, pp.7332-7340 (1987)

(8) 坂本澄彦: 放射線生物学, 秀潤社 (1998)

(9) A. Yokoya, S. M. T. Cunniffe, and P. O'Neill : "Effect of hydration on the induction of strand breaks and base lesions in plasmid DNA films by $\gamma$ -radiation”, J. Am. Chem. Soc., Vol.124, pp.8859-8866 (2002)
(10) B. Boudaiffa, P. Cloutier, D. Hunting, M. A. Huels, and L. Sanche : "Resonant formation of DNA strand breaks by low-energy (3 to $20 \mathrm{eV}$ ) electrons, Science", Vol.287, pp.1658-1660 (2000)

(11) X. Pan, P. Cloutier, D. Hunting, and L. Sanche : "Dissociative electron attachment to DNA", Phys. Rev. Lett., Vol.90, p.208102 (2003)

(12) G. Hanel, B. Gstir, S. Denifl, P. Scheier, M. Probst, B. Farizon, M. Farizon, E. Illenberger, and T. D. Märk : "Electron attachment to uracil", Phys. Rev. Lett, Vol.90, p.188104 (2003)

(13) S.Denifl, S. Ptasinska, M. Cingel, S. Matejcik, P. Scheier, and T. D. Märk : "Electron attachment to the DNA bases thymine and cytosine", Chem. Phys. Lett., Vol.377, pp.74-80 (2003)

(14) M. A. Huels, B. Boudaiffa, P. Cloutier, D. Hunting, and L. Sanche : "Single, double, and multiple double strand breaks induced in DNA by 3-100 eV electrons", J. Am. Chem. Soc., Vol.125, pp.4467-4477 (2003)

(15) K. Washino and W. Schnabel : "Radiation-induced molecular sizechanges in DNA in the presence of p-nitroacetophenone. Pulse radiolysis in conjunction with light-scattering measurements", Int. J. Relat. Biol. Vol.41, pp.271-282 (1982)

(16) I. Yamada, J. Matsuo, Z. Insepov, T. Aoki, T. Seki, and N. Toyoda : "Nano-processing with gas cluster ion beams", Nucl. Instr. And Meth. In Phys. B 164-165, pp.944-959 (2000)

(17) S. Houzumi, K. Mochiji, N. Toyoda, and I. Yamada : "Scanning tunneling microscopy observation of graphite surfaces irradiated with size-selected Ar cluster ion beams", Jpn. J. Appl. Phys. Vol.44, pp.6252-6254 (2005)

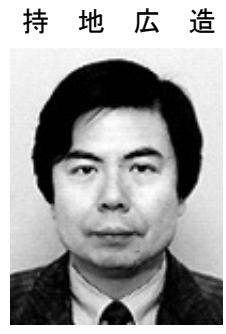

（正員） 1950 年 4 月 30 日生。1975 年東北大 学大学院理学研究科化学専攻修士課程修了。理 学博士, 工学博士。1975 年日立製作所入社, 1988 年同社中央研究所主任研究員。1993-1994 年北 海道大学客員助教授。1994-1997 年 JST さきが け研究 21 (兼務)。2002 年姫路工業大学 (現, 兵庫県立大学) 大学院工学研究科教授。2006 年 より JST 先端計測分析技術機器開発事業チーム 